Mal J Nutr 26(2): 157-164, 2020

\title{
Body mass index of adults, pre-elderly and elderly in Indonesia (Indonesian Family Life Survey 2014)
}

\author{
Ratu Ayu Dewi Sartika \& Eka Rosiyati \\ Department of Public Health Nutrition, Universitas Indonesia, Depok, Indonesia
}

\begin{abstract}
Introduction: Nutritional status is an indicator of health status that can be determined using the Body Mass Index (BMI) $\left(\mathrm{kg} / \mathrm{m}^{2}\right)$. This study aimed to determine factors affecting the nutritional status of adults, pre-elderly, and elderly. Methods: This cross-sectional study used secondary data from 13,655 respondents aged 3666 years that were a part of the 2014 Indonesian Family Life Survey (IFLS). Food consumption patterns, physical activity, and socio-demographic data were used to assess nutritional status (BMI). Results: Consumption patterns of carbohydrates, protein, fat, vegetables, and fruits were significantly associated with mean BMI as an increase in consumption score led to an increase in mean BMI. Conversely, greater physical activity resulted in a decrease in mean BMI. Mean BMI among females was higher than that of males, irrespective of factors such as marital status, unemployment, presence of health insurance, or smoking. Sumatranese people had the highest mean BMI among the population, along with senior high school graduates and high-income earners. Both higher income and education levels led to higher mean BMI. Conclusion: Many factors were shown to affect nutritional status. The results imply that solving nutritional problems in order to improve quality of life will involve many factors, including socioeconomic variables, which are important for designing and evaluating health programmes.
\end{abstract}

Keywords: Nutritional status, adults, pre-elderly, elderly, factors

\section{INTRODUCTION}

Nutritional status is an indicator of health status that can be determined using the Body Mass Index (BMI). BMI is a metric currently used for defining anthropometric characteristics of weight and height in adults, pre-elderly, and elderly, and can be used to classify these populations into relevant groups. The Indonesian Ministry of Health (2013) has stratified BMI as thin $(<18.0 \mathrm{~kg} /$ $\left.\mathrm{m}^{2}\right)$, normal $\left(\geq 18.0-<24.9 \mathrm{~kg} / \mathrm{m}^{2}\right)$, overweight $\left(\geq 25.0-<27.0 \mathrm{~kg} / \mathrm{m}^{2}\right)$, and obese $\left(\geq 27.0 \mathrm{~kg} / \mathrm{m}^{2}\right)$. Numerous clinical consensus panels and public health organisations have recommended that persons with a BMI of $\geq 30 \mathrm{~kg} / \mathrm{m}^{2}$ or those with risk factors of obesity and a BMI of $\geq 25 \mathrm{~kg} / \mathrm{m}^{2}$ to achieve and maintain a lower weight. Additionally, a study by Hwang et al. (2009) found that BMI is a predictor of mortality in the elderly, with obesity $\left(\mathrm{BMI}>25 \mathrm{~kg} / \mathrm{m}^{2}\right)$ being a significant independent predictor for all-cause mortality and overweight $\left(\mathrm{BMI}>23 \mathrm{~kg} / \mathrm{m}^{2}\right)$ elevating the risk of mortality due to cancer, cardiovascular disease, and diabetes. Furthermore, the prevalence of all risk factors in adults, except for diabetes, decreases

\footnotetext{
*Corresponding author: Prof. Ratu Ayu Dewi Sartika Department of Public Health Nutrition, Universitas Indonesia, Depok, Indonesia Tel: (+62)7863501; Fax: (+62)7863501; E-mail: ratuayu.fkm.ui@gmail.com doi: https://doi.org/10.31246/mjn-2019-0045
} 
with a greater reduction in BMI among overweight and obese individuals (Gregg et al., 2006).

The prevalence of obesity in Indonesia continues to increase in both adult men and women (>18 years old). In the last 6 years, the prevalence of obesity among adult women has increased $19.0 \%$ (13.9\% in 2007 to $32.9 \%$ in 2013 ) and $5.8 \%$ among adult men (13.9\% in 2007 and $19.7 \%$ in 2013) (MOH Indonesia, 2013). BMI is an accepted index of obesity in individuals and is also a risk factor for the development of or assessing the prevalence of health concerns, apart from being used for determining public health policies (Nuttal, 2015). Diet, physical activity, and nutritional status are recognised as major determinants of health that are required to monitor direct or indirect changes associated with public health projects (Castetbon et al., 2009).

This study aimed to determine factors affecting the nutritional status of the adult, pre-elderly, and elderly populations in Indonesia using secondary data from the Indonesian Family Life Survey (IFLS) 2014. Specifically, this study sought to answer the following: 1. Socio-demographic profile of the Indonesian people in terms of age, gender, marital status, ethnicity, education, working status, income status, health insurance, smoking status; 2. Nutritional status; 3. Physical activity level; 4. Food consumption patterns; 5 . Relationship between sociodemographic and nutritional status; 6. Relationship between physical activity and nutritional status; and 7 . Relationship between food consumption patterns and nutritional status.

\section{MATERIALS AND METHODS}

A cross-sectional study design was determined to be the best method for analysing BMI and other factors among individuals for a certain time period. This study used secondary data collected during the IFLS, which is publicly accessible at the IFLS5 (2014) domain. Data for IFLS5 were collected between September 2014 and May 2015, and covered 13 selected provinces from IFLS or Sakerti (Indonesian Life Households Survey); specifically, four provinces in Sumatera (North Sumatera, West Sumatera, South Sumatera and Lampung), five provinces in Java (DKI Jakarta, West Java, Yogyakarta, East Java), and four other provinces, including a group of large islands (Bali, West Nusa Tenggara Barat, South Kalimantan, and South Sulawesi). Together, these provinces represented approximately $83.0 \%$ of the Indonesian population (Strauss et al., 2009). The study population $(N=13,655)$ comprised of adults ( $n=10829,36-55$ years), preelderly ( $n=1256,55-59$ years), and elderly ( $n=1570,62-66$ years). This research divided adults into two groups, young adults aged 36-45 years and late adults aged 46-55 years.

Data were collected from adults, pre-elderly and elderly in 2014, and were categorised based on gender. The independent variables for this study were socio-demographic characteristics, physical activity, and consumption patterns, while the dependent variable was nutritional status (BMI). Sociodemographic variables assessed included age, sex, marital status, ethnicity, education, employment status, income status, health insurance, and smoking status. Subjects were divided into three groups in terms of physical activity as: 1 . Not performing regular physical activity (mild, moderate or heavy), 2. Performing physical activity (mild, moderate or heavy) for a period of $<30$ minutes per day, and 3. Performing regular physical activity (mild, moderate or heavy) for a period of $\geq 30$ minutes per day. Consumption patterns were categorised 
into five groups as: 1. Carbohydrate consumption, 2. Protein consumption, 3. Fat consumption, 4. Vegetable consumption, 5. Fruit consumption. Physical activity patterns based on a duration of $<30$ minutes or $\geq 30$ minutes and dietary intake based on frequency (days per week) were determined using questionnaires (secondary data). Univariate and bivariate analyses were performed using the SPSS programme. Univariate analysis was performed as frequency distribution in mean and standard deviation, as well as size of frequency for categorical data, including age, sex, marital status, ethnicity, education, employment status, income status, health insurance, and smoking status. Bivariate analysis was performed using analysis of variance (ANOVA) and independent $t$-test, while Pearson correlation was used to determine the relationship between independent variables and BMI.

\section{RESULTS}

The respondents predominantly (47.1\%) belonged to the age group of $36-45$ years, while $32.2 \%$ were aged 46-55 years, 9.2\% were aged 56-59 years, and $11.5 \%$ were aged $60-66$ years (Table 1 ). The gender of respondents was evenly distributed as $51.1 \%$ were females and 48.9\% were males. Most respondents were married $(86.5 \%)$, were Javanese $(62.8 \%)$, had graduated from senior high school (32.0\%), were employed $(82.0 \%)$, possessed health insurance $(50.8 \%)$ and were non-smokers (59.7\%). In terms of income, as shown in Table 1 , only $4.7 \%$ of respondents were in percentile 2, which corresponds to an income of lesser than 1000,000 rupiahs per year, while many respondents were in percentiles 1 , 4 , and 5 (24.0\% for all).

This study also aimed to obtain information on the consumption patterns, physical activity, and nutritional status of respondents. A consumption score was calculated for each type of nutrient, namely carbohydrate, protein, fat, vegetables, and fruits. These scores were then used to analyse consumption patterns. Table 2 shows that respondents often consumed carbohydrates (55.2\%), proteins $(52.3 \%)$, and fats $(64.6 \%)$ in a week, but rarely consumed vegetables $(52.9 \%)$ or fruits $(51.5 \%)$. With respect to physical activity, most of the respondents reported engaging in physical activity for $\geq 30$ minutes per day $(69.8 \%)$, while the proportions of those who did not engage in any physical activity $(16.4 \%)$ or those who did for $<30$ minutes $(13.8 \%)$ were lower. Most of the respondents (53.3\%) had good nutritional status, while the proportions of obese, overweight, and underweight respondents were $23.7 \%$, $16.6 \%$, and $6.4 \%$, respectively.

Table 3 using bivariate analysis revealed a significant relationship between mean BMI and various socio-demographic characteristics, consumption patterns, and level of physical activity $(p<0.05)$. The mean BMI in adults $\left(24.3 \mathrm{~kg} / \mathrm{m}^{2}\right)$ was higher than that of both the pre-elderly $\left(23.9 \mathrm{~kg} / \mathrm{m}^{2}\right)$ and the elderly $\left(23.2 \mathrm{~kg} / \mathrm{m}^{2}\right)$. Gender of the respondents was also significantly related to mean BMI $(p<0.05)$ as mean BMI in females $\left(25.0 \mathrm{~kg} / \mathrm{m}^{2}\right)$ was higher than that of males $\left(23.2 \mathrm{~kg} / \mathrm{m}^{2}\right)$. Marital status had a significant relationship with mean BMI $(p<0.05)$, whereby married respondents had a higher BMI $\left(24.2 \mathrm{~kg} / \mathrm{m}^{2}\right)$ than respondents who were not married $\left(23.7 \mathrm{~kg} / \mathrm{m}^{2}\right)$. Sumatranese were found to have the highest mean BMI $\left(24.4 \mathrm{~kg} / \mathrm{m}^{2}\right)$, implying that ethnicity may affect mean BMI $(p<0.05)$.

The mean BMI of respondents was significantly related to their education level as a higher education was correlated with a higher mean BMI, and the highest mean BMI $\left(24.7 \mathrm{~kg} / \mathrm{m}^{2}\right)$ was recorded among respondents who had graduated from senior high school. Mean 
Table 1. Socio-demographic profile of respondents $(N=13,655)$

\begin{tabular}{|c|c|c|}
\hline Variables & $n$ & $\%$ \\
\hline \multicolumn{3}{|l|}{ Age (years) } \\
\hline $36-45$ & 6428 & 47.1 \\
\hline $46-55$ & 4401 & 32.2 \\
\hline $56-59$ & 1256 & 9.2 \\
\hline 60-66 & 1570 & 11.5 \\
\hline \multicolumn{3}{|l|}{ Gender } \\
\hline Female & 6973 & 51.1 \\
\hline Male & 6682 & 48.9 \\
\hline \multicolumn{3}{|l|}{ Marital status } \\
\hline Married & 11816 & 86.5 \\
\hline Not married & 1839 & 13.5 \\
\hline \multicolumn{3}{|l|}{ Ethnicity } \\
\hline Sumatera & 1861 & 13.6 \\
\hline Jawa & 8578 & 62.8 \\
\hline Other & 3216 & 23.6 \\
\hline \multicolumn{3}{|l|}{ Level of education } \\
\hline Not graduated in Primary School & 4014 & 29.4 \\
\hline Graduated from Primary School & 3413 & 25.0 \\
\hline Graduated from Junior High School & 1862 & 13.6 \\
\hline Graduated from Senior High School & 4366 & 32.0 \\
\hline \multicolumn{3}{|l|}{ Working status } \\
\hline Unemployed & 2457 & 18.0 \\
\hline Employed & 11198 & 82.0 \\
\hline \multicolumn{3}{|l|}{ Health insurance } \\
\hline Do not have & 6721 & 49.2 \\
\hline Have & 6934 & 50.8 \\
\hline \multicolumn{3}{|l|}{ Income status (per year) } \\
\hline Percentile 1 (Rp 0) & 3276 & 24.0 \\
\hline Percentile $2(<\operatorname{Rp} 1,000,000)$ & 635 & 4.7 \\
\hline Percentile $3(\geq \operatorname{Rp~} 1,000,000-<\operatorname{Rp~10,000,000)}$ & 3192 & 23.4 \\
\hline Percentile $4(\geq \operatorname{Rp~} 10,000,000-<\operatorname{Rp} 20,000,000)$ & 3271 & 24.0 \\
\hline Percentile $5(\geq \operatorname{Rp} 20,000,000)$ & 3281 & 24.0 \\
\hline \multicolumn{3}{|l|}{ Smoking status } \\
\hline No smoking & 8149 & 59.7 \\
\hline Smoking & 5506 & 40.3 \\
\hline
\end{tabular}

BMI increased with increasing income, whereby respondents with the highest income ( $>20$ million rupiahs) had the highest mean BMI $\left(24.7 \mathrm{~kg} / \mathrm{m}^{2}\right)$.

A significant negative relationship was observed between mean BMI with employment status and having medical insurance $(p<0.05$ for both). The mean BMI of unemployed respondents $\left(24.9 \mathrm{~kg} / \mathrm{m}^{2}\right)$ was higher than that of employed respondents $\left(23.9 \mathrm{~kg} / \mathrm{m}^{2}\right)$. Furthermore, respondents possessing health insurance had a higher mean BMI $\left(24.3 \mathrm{~kg} / \mathrm{m}^{2}\right)$ than those without health insurance $\left(23.9 \mathrm{~kg} / \mathrm{m}^{2}\right)$. The higher mean BMI of those who were unemployed may have been caused by the lack of physical activity in this population. Non-smokers had a greater BMI $\left(24.9 \mathrm{~kg} / \mathrm{m}^{2}\right)$ than smokers $\left(22.9 \mathrm{~kg} / \mathrm{m}^{2}\right)$. The mean BMI of respondents was significantly related to physical activity. Respondents who did not have any physical activity $(24.3 \mathrm{~kg} /$ $\mathrm{m}^{2}$ ) or were engaged in $<30$ minutes per day of physical activity $\left(24.4 \mathrm{~kg} / \mathrm{m}^{2}\right)$ had greater mean BMI than respondents 
Table 2. Consumption patterns, physical activity and nutritional status of respondents $(N=13,655)$

\begin{tabular}{|c|c|c|}
\hline Variables & $n$ & $\%$ \\
\hline \multicolumn{3}{|l|}{ Consumption of carbohydrates } \\
\hline Seldom (<3 days/week) & 6117 & 44.8 \\
\hline Often ( $\geq 3$ days /week) & 7538 & 55.2 \\
\hline \multicolumn{3}{|l|}{ Consumption of proteins } \\
\hline Seldom (<2 days/week) & 6507 & 47.7 \\
\hline Often ( $\geq 2$ days/week) & 7148 & 52.3 \\
\hline \multicolumn{3}{|l|}{ Consumption of fats } \\
\hline Seldom (<1 days/week) & 4838 & 35.4 \\
\hline Often ( $\geq 1$ days/week) & 8817 & 64.6 \\
\hline \multicolumn{3}{|l|}{ Consumption of vegetables } \\
\hline Seldom (<3 days/week) & 7220 & 52.9 \\
\hline Often ( $\geq 3$ days/week) & 6435 & 47.1 \\
\hline \multicolumn{3}{|l|}{ Consumption of fruits } \\
\hline Seldom (<1 days/week) & 7037 & 51.5 \\
\hline Often ( $\geq 1$ days /week) & 6618 & 48.5 \\
\hline \multicolumn{3}{|l|}{ Physical activity } \\
\hline No physical activity & 2245 & 16.4 \\
\hline Physical activity $<30 \mathrm{~min}$ & 1882 & 13.8 \\
\hline Physical activity $\geq 30$ min & 9528 & 69.8 \\
\hline \multicolumn{3}{|l|}{ Nutritional status } \\
\hline Underweight $\left(\mathrm{BMI}<18.5 \mathrm{~kg} / \mathrm{m}^{2}\right)$ & 875 & 6.4 \\
\hline Normal $\left(\mathrm{BMI} \geq 18.5-<24.9 \mathrm{~kg} / \mathrm{m}^{2}\right)$ & 7280 & 53.3 \\
\hline Overweight $\left(\mathrm{BMI} \geq 24.9-<27.0 \mathrm{~kg} / \mathrm{m}^{2}\right)$ & 2266 & 16.6 \\
\hline Obese $\left(\mathrm{BMI} \geq 27.0 \mathrm{~kg} / \mathrm{m}^{2}\right)$ & 3234 & 23.7 \\
\hline
\end{tabular}

who were engaged in physical activity for $\geq 30$ minutes per day $\left(24.0 \mathrm{~kg} / \mathrm{m}^{2}\right)$. A significant positive relationship was seen between consumption patterns and mean BMI $(p<0.05)$. Table 3 shows that respondents who frequently consumed carbohydrates, proteins, fats, vegetables, and fruits in a week had greater mean BMI than those who did not, implying that when various nutritional needs are met, the individual's nutritional status remains adequate.

\section{DISCUSSION}

In this study, BMI in adults was higher than that of both the pre-elderly and elderly. Meeuwsen, Horgan \& Elia (2010) have stated that differences in age, BMI distribution, and possible loss of muscle may be compensated by an increase in other body components, and that it may be due to age-related decrease in the extracellular fluid relative to intracellular water (an indicator of body cell mass), especially in the elderly. Another explanation is survival bias. Obese persons are more likely to die earlier at a younger age, so those who survived into old age are selectively healthier. This commensurates with the recent observation of a population sub-group of obese people who were 'metabolically healthy' and therefore confounded due to prior disease-associated unintentional weight loss (Ng et al., 2017).

Gender was significantly related to BMI, whereby females had a higher BMI than males. This difference can be attributed to body composition differences between males and females, as females generally have a higher percentage of body fat than males. Data from the study by Blaak (2001) also 
Table 3. Relationship between socio-demographics, consumption patterns and physical activity with mean BMI of respondents $(N=13,655)$

\begin{tabular}{|c|c|c|c|}
\hline Variables & $\begin{array}{c}B M I\left(\mathrm{~kg} / \mathrm{m}^{2}\right) \\
\text { Mean }(\mathrm{SD})\end{array}$ & $p$-value & $95 \% C I$ \\
\hline \multicolumn{4}{|l|}{ Age (years) } \\
\hline $36-45$ & $24.3(3.9)$ & $<0.001^{* * *}$ & $-1.35--0.76$ \\
\hline $46-55$ & $24.3(3.9)$ & $<0.001^{* * *}$ & $-1.35--0.74$ \\
\hline $56-59$ & $23.9(4.0)$ & $<0.001^{* * *}$ & $-1.03--0.24$ \\
\hline 60-66 & $23.2(3.9)$ & & \\
\hline \multicolumn{4}{|l|}{ Gender } \\
\hline Female & $25.0(4.0)$ & $<0.001^{* * *}$ & $1.73-1.99$ \\
\hline Male & $23.2(3.6)$ & & \\
\hline \multicolumn{4}{|l|}{ Marital status } \\
\hline Not Married & $23.7(3.9)$ & $<0.001^{* * *}$ & $-0.71--0.32$ \\
\hline Married & $24.2(3.9)$ & & \\
\hline \multicolumn{4}{|l|}{ Ethnicity } \\
\hline Sumatera & $24.4(3.9)$ & & \\
\hline Jawa & $24.2(3.9)$ & $0.049^{*}$ & $0.00-0.48$ \\
\hline Lainnya & $23.9(3.9)$ & $<0.001^{* * *}$ & $0.28-0.84$ \\
\hline \multicolumn{4}{|l|}{ Education } \\
\hline Not graduated in Primary School & $23.6(4.0)$ & & \\
\hline Graduated in Primary School & $23.9(3.9)$ & $0.005^{* *}$ & $-0.54--0.07$ \\
\hline Graduated in Junior High School & $24.3(3.9)$ & $<0.001^{* * *}$ & $-1.06--0.48$ \\
\hline Graduated in Senior High School & $24.7(3.8)$ & $<0.001^{* * *}$ & $-1.41--0.96$ \\
\hline \multicolumn{4}{|l|}{ Working status } \\
\hline Unemployed & $24.9(4.0)$ & $<0.001^{* * *}$ & $0.79-1.15$ \\
\hline Employed & 23.9 (3.9) & & \\
\hline \multicolumn{4}{|l|}{ Income } \\
\hline Percentile 1 (Rp 0) & $24.6(4.1)$ & $<0.001^{* * *}$ & $-1.53--0.58$ \\
\hline Percentile $2(<\mathrm{Rp} 1,000,000)$ & $23.5(4.0)$ & & \\
\hline Percentile $3(\geq \operatorname{Rp} 1,000,000-<\operatorname{Rp~10,000,000)}$ & $23.6(3.9)$ & 1.000 & $-0.58-0.37$ \\
\hline Percentile $4(\geq \operatorname{Rp} 10,000,000-<\operatorname{Rp} 20,000,000)$ & $23.7(3.8)$ & 1.000 & $-0.63-0.32$ \\
\hline Percentile $5(\geq \operatorname{Rp} 20,000,000)$ & $24.7(3.8)$ & $<0.001^{* * *}$ & $-1.67--0.71$ \\
\hline \multicolumn{4}{|l|}{ Health insurance } \\
\hline Don't have & 23.9 (3.9) & $<0.001^{* * *}$ & $-0.41--1.46)$ \\
\hline \multirow{2}{*}{\multicolumn{4}{|c|}{ Smoking status }} \\
\hline & & & \\
\hline No smoking & $24.9(3.9)$ & $<0.001^{* * *}$ & $1.80-2.07$ \\
\hline \multirow{2}{*}{\multicolumn{4}{|c|}{ Physical activity }} \\
\hline & & & \\
\hline No physical activity & $24.3(4.0)$ & $0.01 *$ & $-0.54--0.05$ \\
\hline Physical activity $<30$ min & $24.4(3.9)$ & $<0.001^{* * *}$ & $-0.65--0.17$ \\
\hline Physical activity $\geq 30 \mathrm{~min}$ & $24.0(3.9)$ & & \\
\hline \multicolumn{4}{|l|}{ Consumption of carbohydrates } \\
\hline Seldom $(<3$ days/week) & $24.0(3.9)$ & $0.002^{* *}$ & $-0.34--0.08$ \\
\hline Often ( $\geq 3$ days/week) & $24.2(3.9)$ & & \\
\hline \multicolumn{4}{|l|}{ Consumption of protein } \\
\hline Seldom ( $<2$ days/week) & $23.9(3.9)$ & $<0.001^{* * *}$ & $-0.58--0.31$ \\
\hline Often ( $\geq 2$ days/week) & $24.4(3.9)$ & & \\
\hline \multicolumn{4}{|l|}{ Consumption of Fat } \\
\hline Seldom $(<1$ days /week) & $23.9(3.9)$ & $<0.001^{* * *}$ & $-0.54--0.26$ \\
\hline Often ( $\geq 1$ days / week) & $24.3(3.9)$ & & \\
\hline \multicolumn{4}{|l|}{ Consumption of vegetables } \\
\hline Seldom $(<3$ days/week $)$ & $24.0(3.9)$ & $0.049 *$ & $-0.27--0.00$ \\
\hline Often ( $\geq 3$ days/week) & $24.2(3.9)$ & & \\
\hline \multicolumn{4}{|l|}{ Consumption of fruits } \\
\hline Seldom (<1 days/week) & 23.9 (3.9) & $<0.001^{* * *}$ & $-0.68--0.41$ \\
\hline Often ( $\geq 1$ days / week) & 24.4 (3.9) & & \\
\hline
\end{tabular}

${ }^{*} p<0.05$

$* * p<0.01$

$* * * p<0.001$ 
showed that basal oxidation (adjusted for fat-free mass) is lower in females compared to males, thereby contributing to higher fat storage in women.

Marital status had a significant relationship with BMI, in which married respondents had a higher BMI than those who were not married. These results are in line with a study by Lipowicz, Gronkiewicz \& Malina (2002) in Poland, which reported that married individuals had a higher BMI than those who were never married, in all age and educational groups analysed. Cobb et al. (2016) found that women gained more weight than men, and there was a stronger association between changes in the husband's BMI and that of the wife's, suggesting that marriage may lead to a wife's weight-related behaviours being influenced by their husbands, rather than vice-versa.

The result of BMI being related to education level is consistent with that reported by Zhoua et al. (2017), which stated that greater BMI was observed among those with elementary or higher education level compared to those who were less educated. Importantly, higher levels of education are associated with better socioeconomic status that is supported by greater incomes. Higher income therefore grants greater purchasing power to buy nutritious foods.

Non-smokers had a greater BMI than smokers. This is in agreement with results published by Jitnatrin et al. (2014) showing that BMI among male and female smokers were lower than male and female non-smokers, respectively. This may be due to the elevation in metabolic rate and/or reduced appetite caused by nicotine in smokers.

The benefits of optimum physical activity are apparent when BMI among respondents engaging in $<30$ minutes and $\geq 30$ minutes per day of physical activity were compared as BMI decreased when duration of activity increased. Sun, Norman \& While (2013) have reported that regular physical activity can lead to significant health improvements at all ages and that it can prolong the active years of independent living, apart from enhancing the quality of life for the elderly. Nelson et al. (2007) have recommended that the aim of physical activity for the elderly should be to increase the volume of aerobic physical activity to prevent unhealthy weight gain. There is evidence that an increase in physical activity is related to the prevention of weight gain, but a clear dose-response effect has yet to be established. The recommended goal includes moderate aerobic physical activity performed for 30-60 minutes per day. Interestingly, the fat-free mass accounts for $19.0 \%$ of weight gain due to decreasing physical activity while it represents $33.0 \%$ of weight loss in people who experience a decrease in weight (Hughes et al., 2002). These observations imply that the duration of physical activity is related to body weight.

The strength of this study was that it represented the majority of the population in Indonesia which is spread across various provinces including urban and rural areas. The limitations of this study were its cross-sectional design and its use of bivariate, not multivariate analysis, to determine factors influencing BMI. Consequently, confounders could be adjusted for in this study. There were also limited information about portion of foods, variety of fruits and vegetables, duration of physical activity in this study.

\section{CONCLUSION}

Using BMI as an index, we showed that many factors affected nutritional status, such as age, gender, marital status, ethnicity, education, employment status, income status, health insurance, 
smoking status, physical activity, and consumption patterns. These results strongly advocate the importance of nutrition improvement programmes that will help improve the quality of life among adults and elderly.

\section{Authors' contributions}

RADS, conceptualised and designed the study and reviewed the manuscript; ER, conducted the study, data collection, data analysis and drafting of the manuscript.

\section{Conflict of interest}

There is no conflict of interest

\section{References}

Blaak E (2001). Gender differences in fat metabolism. Curr Opin Clin Nut Metab Care 4(6):499-502.

Castetbon K, Vernay M, Malon A, Salanave B, Deschamps V, Roudier C, Oleko A, Szego E \& Hercberg S (2009). Dietary Intake, physical activity and nutritional status in adults: the French nutrition and health survey (ENNS, 2006-2007). Br J Nutr 102(5):733-743.

Cobb LK, McAdams-DeMarco MA, Gudzune KA, Anderson CA, Demerath E, Woodward M, Selvin E \& Coresh J (2016). Changes in body mass index and obesity risk in married couples over 25 years old the ARIC cohort study. Am J Epidemiol 183(5):435-443.

Gregg EW, Cheng, YJ, Cadwell BL, Imperatore G, Williams DE, Flegal KM, Narayan KM \& Williamson DF (2006). Secular trends in cardiovascular disease risk factors according to body mass index in US adults. JAMA 293(15):1868-1874.

Hughes VA, Frontera WR, Roubernoff R Evans WJ \& Singh MA (2002). Longitudinal changes in body composition in older man and women: role of body weight change and physical activity. Am J Clin Nut 76(2):473- 481.

Hwang LC, Chen SC, Tjung JJ, Chiou HY, Chen CJ \& Tsai CH (2009). Body mass index as a predictor of mortality in older people in Taiwan. Int $J$ Gerontol 3(1):39-46.

Jitnatrin N, Kosulwat V, Rojroongwasinkul N, Boonpradem A, Haddock CK \& Poston WSC (2014). The relationship between smoking, body weight, body mass index, and dietary intake among Thai adults: results of the national Thai food. Asia Pac J Public Health 26(5):481- 493.
Lipowicz A, Gronkiewicz S \& Malina RM (2002). Body mass index, overweight and obesity in married and never married men and women in Poland. Am J Hum Biol 14(4):469-475.

Meeuwsen S, Horgan GW \& Elia M (2010). The relationship between BMI and percent body fat, measured by electrical impedance, in a large adult sample is curvilinear and influenced by age and sex. Clin Nutr 29(5):560-566.

$\mathrm{MOH}$ Indonesia (2013). Indonesian Basic Health Research. Department of Health Research and Development, Ministry of Health Indonesia, Jakarta.

Nelson ME, Rejeski WJ, Blair SN, Duncan PW, Judge JO, King, AC, Macera CA \& CastanedaSceppa C (2007). Physical activity and public health in older adults: recommendation from the American College of Sports Medicine and the American Heart Association. Med Sci Sports Exerc 39(8):1435-1445.

Ng TP, Jin A, Chow KY, Feng L, Nyunt MSZ \& Yap KB (2017). Age dependent relationship between body mass index and mortality: Singapore longitudinal ageing study. PLOS ONE 12 (7):111

Nuttal FQ (2015). Body mass index: obesity, BMI, and health: A critical review. Nutr Today 50(3):117-128.

Strauss J, Witoelar F, Sikoki B \& Wattie AM (2009). The fourth wave of the Indonesia Family Life Survey: Overview and field report. WR-675/1NIA/NICHD. RAND, Santa Monica, California.

Sun F, Norman IJ \& While AE (2013). Physical activity in older people: A systematic review. BMC Public Health 13:449.

Zhoua M, Feng X, Yong J, Li Y, Zhang M, Page A, Astell-Burt T \& Zhao W (2017). Lifting the lid on geographic complexity in the relationship between body mass index and education in China. Health Place 46:1-5. 